\title{
In Memoriam PAPP LÁSZLó
}

\author{
SOLTÉSZ ZOLTÁN ${ }^{1}$ * és PEREGOVITS LÁSZLÓ ${ }^{2}$ \\ ${ }^{1}$ Ökológiai Kutatóközpont, Lendület Ökoszisztéma-szolgáltatás Kutatócsoport \\ H-2163 Vácrátót, Alkotmány utca 2-4. \\ *E-mail: soltesz.zoltan@ecolres.hu \\ ${ }^{2}$ Pars Szoftverház Kft., H-2094 Nagykovácsi, Balta utca 11. \\ E-mail: laszlo.peregovits@gmail.com
}

\begin{abstract}
A baranyai Aranyosgadányban született 1946. október 3-án. A pécsi Nagy Lajos Gimnázium után, az ELTE Természettudományi Kar biológus szakán folytatta tanulmányait. Középiskolás korában, majd első egyetemi éveiben főleg a madarak és kisemlősök érdekelték. BALOGH JÁNOS produkcióbiológiai speciálkollégiumán szóba került B. R. LAWRENCE (1954) marhalepényeken végzett vizsgálata, melyek során azt találta, hogy a lepottyanó trágya súlyának 1\%-a alakul át légylárvatömeggé. Óra után odament BALOGH professzorhoz LACI és azt mondta neki: „Én ezt nem hiszem”. Mire BALOGH professzor kis gondolkodás után rávágta: „Nagyon jó! De akkor te megmérhetnéd ezt Magyarországon!” Így kezdett el BALOGH JÁNOS biztatására - aki egész pályáját figyelemmel kísérte s támogatta - trágyalebontó legyek produkcióbiológiájával foglalkozni. Szakdolgozatát, majd egyetemi doktori értekezését is a marhalepényekben fejlődő legyek ökológiájáról írta. 1970-ben a Természettudományi Múzeum Állattárának Légygyüjteményében kezdte kutatói pályafutását, ahol a gyüjteményi gyüjtő-feldolgozó munka mellett is folytatta ökológiai kutatásait. „Trágyában fejlödö legyek komplex vizsgálata" címü kandidátusi dolgozatát 1976-ban védte meg.

1981-től egy évig a vecsési 4. sz. Általános Iskolában tanított kémiát és biológiát. 1982ben hívták az Állatorvostudományi Egyetemre, mert Zoológia tárgyat indítottak, és ki kellett dolgozni a tananyagot. 1986-ig tanított az Általános Állattani és Parazitológiai Tanszéken. Ezek a kis kitéröi egyáltalán nem látszanak meg a publikációs listájában. Ezt követően 2010-es nyugdíjba vonulásáig újra az Légygyüjteményben dolgozott.

MTA-doktori értekezését (,A taxonómia eredményeinek felhasználása a legyekkel kapcsolatos gyakorlati feladatok megoldásában") 1988-ban védte meg. 1990-ben választották meg a Magyar Tudományos Akadémia levelező, majd 1998-ban rendes tagjává.

Életét és munkásságát a múzeumi munka határozta meg, s mindig azt mondta, hogy a legnagyobb érdeme maga a gyüjtemény. A légygyüjtemény 1971 végén 330.000 kataszteres példányt számlált, nyugdíjba vonulásakor ez a szám meghaladta az egymilliót. A hazai gyüjtések mellett 27 országban gyüjtött (legjelentősebbek Afganisztán, India, Thaiföld, Vietnám (1. ábra), Tajvan, Kína, Dél-Afrika). A gyüjteményépítés mellett, termékeny taxonómus is volt. Öt tudományra új családot/alcsaládot (Risidae L. PAPP, 1977; Tunisimyiidae L. PAPP, 1980; Nannodastiinae L. PAPP, 1980; Stenomicridae L. PAPP, 1984; Circumphallidae L. PAPP, 2011), 97 új genuszt és 747 új légyfajt írt le. A hazánkból ma ismert légyfajok majd' harmadát (több, mint 2000 fajt) ő mutatta ki.
\end{abstract}




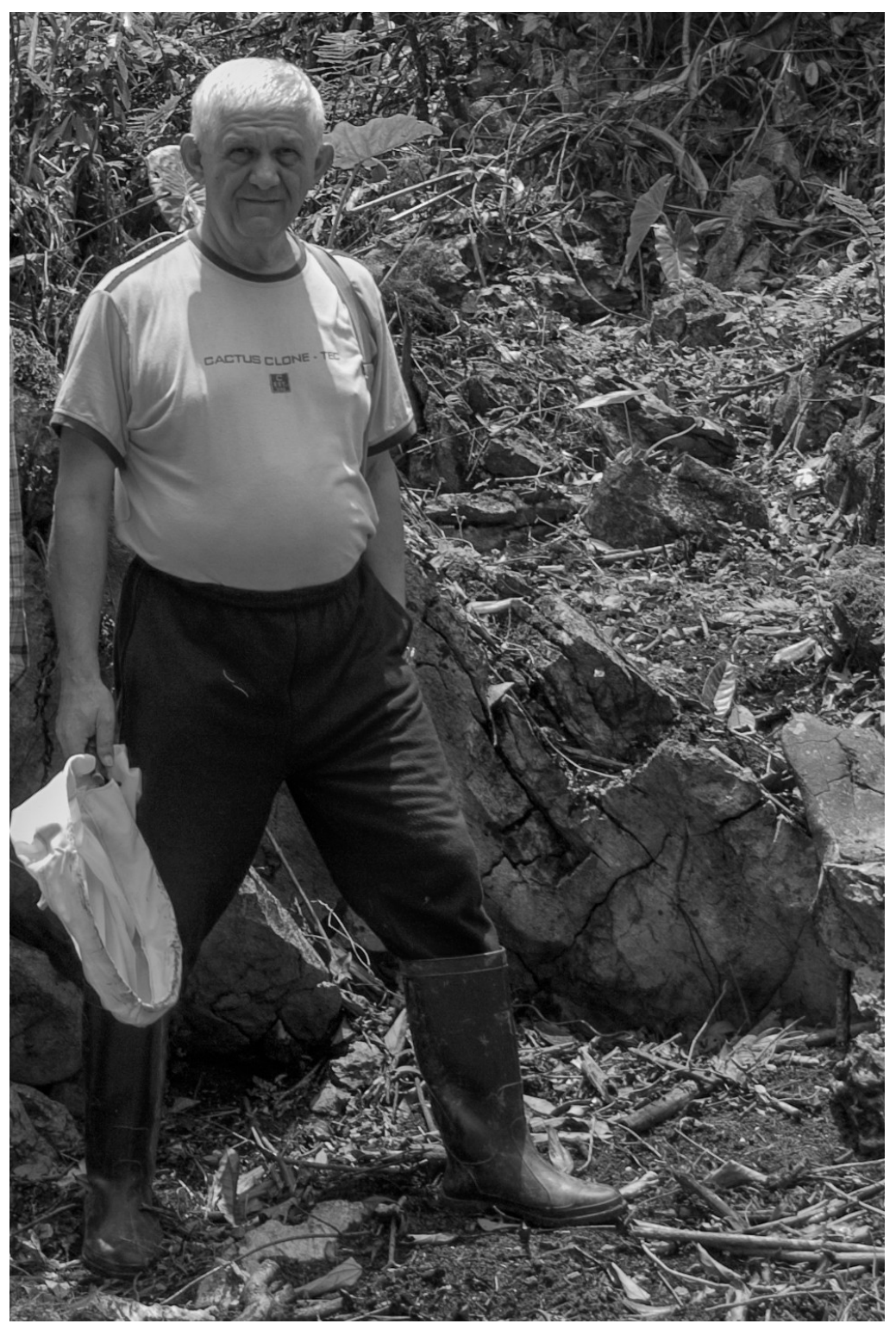

1. ábra. PAPP LÁSZLÓ Vietnámban 2010-ben

Figure 1. LÁSZLÓ PAPP in Vietnam, 2010 
Kvantitatív ökológiai munkáiban hatalmas méretü mintasorozatokat dolgozott fel, így tudta igazolni, hogy a légyfajok nagy többsége ritka, azaz 0,1\%-nál kisebb a gyakoriságuk a teljes mintában (PAPP 1993).

368 könyvet, könyvfejezetet és tudományos folyóiratcikket írt, melyekre több mint 2700 független citációt kapott.

Három, nemzetközileg is kiemelkedő könyvsorozatban is meghatározó szerepe volt. A SoÓs ÁRPÁDdal együtt szerkesztett 13 kötetes Catalogue of Palaearctic Diptera (19841993) könyvsorozat 58 szerző tollából, több mint 5000 oldalon (17 fejezetet ő írt) jelent meg. A DARVAS BÉLÁval együtt szerkesztett Contributions to a Manual of Palaearctic Diptera (1996-2000) sorozat négy kötete több mint 3000 oldalon jelent meg. Utolsó nagy könyvsorozata, az Agromyzidae (Diptera) of Hungary, négy kötetben jelent meg, melyeket cseh kollégájával, MILOŠ ČERNÝvel közösen írt meg 1880 oldalon, közel 6300 ábrával.

1996-ban jelent meg a Zootaxonómia egységes egyetemi jegyzet, melyet ő szerkesztett, ezt valamennyi felsőoktatási intézményben használták. 2021-ben jelent meg a Zootaxonómia kézikönyv, melynek egyik szerkesztője volt, de a kész könyvet sajnos már nem vehette kézbe.

Alapításától kezdve 16 éven át vezette az MTA-MTM Ökológiai Kutatócsoportját. Kilenc évig volt tagja az MTA Bolyai János Kutatási Ösztöndíj kuratóriumának. Szolgált az OTKA szervezetében és a Magyar Akkreditációs Bizottságban. Meghatározó szerepet játszott az Acta Zoologica Academiae Scientiarum Hungaricae folyóirat megújításában, melynek föszerkesztője is volt egy ideig.

1982-2014 között számos hazai egyetemen oktatott az alapkurzustól a PhD kurzusig, s több tucatnyi hallgatónak volt a témavezetője.

1996-tól 2012-ig az International Commission on Zoological Nomenclature tagja. 1991től a Royal Entomological Society tagja (fellow). A Magyar Rovartani Társaságnak 1965 től tagja, 1975-1977 között pedig titkára. Alapító tagja a Magyar Ökológusok Tudományos Egyesületének és a Magyar Parazitológusok Társaságának.

1986-ban DARVAS BÉLÁval megszervezték Budapesten az első legyész világkongreszszust, mely sorozat napjainkig él (International Congress of Dipterology).

Elismerésekben sem volt hiánya. Az OTKA-tól Ipolyi Arnold Tudományfejlesztési Díjat, a Magyar Ökológusok Tudományos Egyesületétől „A Magyar Ökológiáért” díjat, a Magyar Rovartani Társaságtól a Frivaldszky Imre Emlékplakett bronz és arany fokozatát, valamint a Magyar Parazitológusok Társaságától emlékérmet kapott. 2004-ben Széchenyidíjban részesült.

Halálos betegen befejezett cikkében (PAPP 2021) így búcsúzik kollégáitól:

„Farewell remark. Dear Readers, this is my last paper in the taxonomy of Sphaeroceridae. In the last 50 years, I published much as regards the volume of books, book chapters and scientific papers. As for their quality, it is out of my competence to judge them. Those who used them with benefit are welcome. If I caused you annoyance, I beg your pardon. God bless you all."

Az írás alapját PEREGOVITS \& SOLTÉSz (2021) munkája képezte. 


\section{Irodalomjegyzék}

LAWRENCE B. R. 1954. The larval inhabitants of cowpats. Journal of Animal Ecology 23: 234-260.

PAPP L. 1993. A repülő rovarok abundanciájáról. A légyfogás elmélete. Akadémiai székfoglaló, 1991. április 30. Akadémiai Kiadó, Budapest, 46 pp.

PAPP L. 2021. New species of Apterobiroina L. Papp and Bentrovata Richards (Diptera, Sphaeroceridae) from Australia. Acta Zoologica Academiae Scientiarum Hungaricae 67(2): 101117. https://doi.org/10.17109/azh.67.2.101.2021

Peregovits L. \& Soltész Z. 2021. In memoriam Prof. László Papp. Acta Zoologica Academiae Scientiarum Hungaricae 67(2): 99-100. 


\title{
In Memoriam LÁSZLó PAPP
}

\section{ZOLTÁN SOLTÉSZ ${ }^{1 *}$ and LÁSZLÓ PEREGOVITS ${ }^{2}$}

\author{
${ }^{1}$ Lendület Ecosystem Services Research Group, Centre for Ecological Research \\ Alkotmány utca 2-4, H-2163 Vácrátót, Hungary \\ *E-mail: soltesz.zoltan@ecolres.hu \\ ${ }^{2}$ Pars Szoftverház Ltd., Balta utca 11, H-2094 Nagykovácsi, Hungary \\ E-mail: laszlo.peregovits@gmail.com
}

ÁLLATTANI KÖZLEMÉNYEK (2021) 106(1-2): 000-000.

\begin{abstract}
LÁszló PAPP, ordinary member of the Hungarian Academy of Sciences, Fellow of the Royal Entomological Society, died at the age of 75 in 2021. His entire dipterist carrier closely linked with the Hungarian Natural History Museum. He was an excellent curator. The Diptera collection counted 330,000 specimens when he became a curator and reached a million by the time he retired. He described five new families or subfamilies, 97 new genera and 747 new species for science, and discovered more than 2,000 Diptera species for the fauna of Hungary. He authored 368 articles, book chapters and books, and co-edited three outstanding series (Catalogue of Palaearctic Diptera, Contributions to a Manual of Palaearctic Diptera, Agromyzidae (Diptera) of Hungary). Together with Prof. BÉLA DARVAS, they launched the series of International Congress of Dipterology and organised its inaugural event in Budapest in 1986. He was active member of professional societies (Hungarian Entomological Society, Hungarian Parasitological Society, Hungarian Association of Ecologists, Royal Entomological Society). His role in higher zoological education was indispensable in Hungary.
\end{abstract}

